\title{
Life Stories: A Way to Explore Language Learners' Narrative Experiences and Identities in an EFL Context
}

\author{
Historias de vida: una manera de explorar experiencias \\ e identidades de aprendices de lengua en un \\ contexto de inglés como lengua extranjera
}

Histórias de vida: um jeito de explorar experiências e identidades de aprendizagens de língua num contexto de inglês como língua estrangeira

Diego Ubaque ${ }^{1}$

\section{Abstract}

This narrative study explores real-life experiences around language learning and around language learners' identities that emerge considering the act of positioning within an in situ perspective. Thinking of the language learner as a subject with agency, the study presents accounts of the empowered and disempowered language learner as narrated in life stories. The study took on analytical elements of grounded theory (Charmaz, 2006) to approach the life story as unit of analysis. Data collected unveiled that learners resist to positioning within the learning environment, and as a result they can exercise their agentic selves. The analysis also shed light into the importance of considering not just linguistic background but also the experiential one to get to understand learners from a very ontological but narrative perspective.

Keywords: narrative, identity, life story, language learning.

Resumen

Este trabajo explora las experiencias de la vida real en torno al aprendizaje de idiomas y de identidades que emergen teniendo en cuenta el acto de posicionamiento dentro de una perspectiva situada. Pensando en el aprendiz de la lengua como un sujeto con la capacidad de actuar, el estudio da cuenta del alumno con poder y sin poder tal cual como se narra en las historias de vida. El estudio tomó en cuenta elementos analíticos de la teoría fundamentada (Charmaz, 2006) para acercarse a la historia de vida como unidad de análisis. Los datos recogidos revelaron que los alumnos se resisten al posicionamiento dentro del ambiente de aprendizaje y, como resultado, pueden actuar. El análisis también arrojó luz sobre la importancia de tener en cuenta no solo los antecedentes lingüísticos, sino también la experiencia, para llegar a comprender a los alumnos desde una perspectiva no solo ontológica, sino narrativa.

Palabras clave: narrativa, identidad, historia de vida, aprendizaje de lengua.

Resumo

Este trabalho explora as experiências da vida real em torno a aprendizagem de idiomas e de identidades que emergem, tendo em conta 0 ato de posicionamento dentro duma perspectiva situada. Pensando no aprendiz da língua como um sujeito com a capacidade de atuar, o estudo da conta do aluno com poder e sem poder tal qual como se narra nas histórias de vida. 0 estudo tomou elementos analíticos da teoria fundamentada (Charmaz, 2006), para aproximar-se à história de vida como unidade da análise. Os dados recolhidos, revelaram que os alunos se resistem ao posicionamento dentro do ambiente de aprendizagem e, como resultado, podem atuar. A análise também deu luz sobre a importância de ter em conta não só os aconteceres linguísticos, mas também a experiência, para chegar a compreender aos alunos desde uma perspectiva não só ontológica, mas narrativa.

Palavras-chave: narrativa, identidade, história de vida, aprendizagem da língua.

Artículo recibido el 21 de marzo de 2015 y aprobado el 26 de junio de 2015

1 Universidad Pedagógica Nacional, Bogotá, Colombia. Correo electrónico: diegoubaque@gmail.com 


\section{Introduction}

The learners' perception of their educational experiences has been distinguished to provide valuable insights in their learning process (Benson and Nunan, 2014). With the emphasis placed on the learner, it has witnessed an epistemological movement of using narrative accounts in language learning research (Bell, 2002; Pavlenko, 2007). Researchers have guided their attention to more complex issues that locate learners as social beings and as the result of social relations (Berger \& Luckmann, 1966), many of them have claimed narrative inquiry is a tool that offers alternative ways to examine issues that are otherwise inaccessible using more experimental methodologies (Clandinin \& Connelly, 2000).

Not surprisingly, researchers within the field of language learning have tried to put in the right place the voices of those who are traditionally seen as the objects of the research process (Rubdy, 2009), in order to move away from a particular and linguistic understanding to a more situated approach to the language learner (Norton, 2000). Therefore, learners' narrative accounts of the learning experience, that radically alter learners' relationship to other users or learners of the language they speak or relate to, turn out to be quite informative, regarding their language learning process and the learner's own identity.

With this in mind, this article presents some of the corpus of analysis used to explore language learner's narrative identities and experiences within an EFL context. To this respect, it is worth noting from a position of hindsight that data used here echoes the notion that as human beings, we are creatures who construct narratives to explain our experience as well as past, present and imagined world experiences (Sikes and Gale, 2006). Hence, learners' narrations and accounts of the learning experience mainly claim that stories can help understand the world of teaching and learning, since stories are implied in the learners' experience.

\section{Narrative Inquiry: The life story}

Being an interdisciplinary approach and tool to inquiry, the term narrative has been defined and contextualized depending on its use in different fields. De Fina and Georgakopoulou (2012) claim that a "narrative resists straightforward and agreedupon definitions and conceptualizations." Taylor (2003) also states that "narrative studies is a broad field encompassing a range of theoretical assumptions and analytical approaches", and Stanley and Temple (2008) concur, saying that there is little shared sense of core concerns, of approach and even of what narrative is seen as. This may be due to the different and interdisciplinary conceptions of "narrative". Not surprisingly, narrative as a tool for reflection and analysis has been explored across many disciplines.

According to Barkhuizen, Benson \& Chik (2014) Narrative Inquiry brings storytelling and research together either by using stories as research data or by using storytelling as a tool for data analysis or presentation of findings. Narrative inquiry is undoubtedly the only methodology that provides access to language teaching and learning as lived experiences that take place all over periods of time and in multiple settings and contexts. Thus, being narrative inquiry a means to an end, this study takes on the definition of narrative as the discourse or way of using language to construct stories (Bruner, 1990) in order to dig into language learner's narrative identities and experiences within an EFL context.

Bearing the aforementioned in mind, narrative is the means whereby individuals define and recreate themselves through the discursive construction of identity (Martinez-Roldan, 2003), that being the case, not only is the narrative one of the best ways of learning about individuals' worlds by inspecting the verbal accounts of the experienced reality (Roberts, 2002) but also it is "an especially apt approach to investigate how language teachers and learners are situated in specific social, historical, and cultural contexts, in which the primary is viewed as the teachers' and learner's lives (Barkhuizen, Benson \& Chik, 2014, 11). From such a perspective, a narrative mode of knowing may explain experience way better instead of breaking it into pieces; interestingly, there is recognition on the application of narrative 
as a research theory. In this line of thought, Lantolf (2000) states that this new approach treats language learners not as "processing devices," but as "people" who "actively engage in constructing the terms and conditions of their own learning" (p. 145). Therefore, this study will underpin Narrative Inquiry as the method of study and oral narrations or "life stories" as the experiences expressed in lived and told stories of language learners. Life stories, therefore, become the means of investigating social phenomena from the perspectives of the "changing experiences and outlooks of individuals in their everyday lives" (Roberts, 2002, 1).

\section{Identity: From Etymology to Epistemology}

Understanding identity as a fragmented and not fixed entity conceived as an ongoing process, involves the interpretation, and reinterpretation of experiences as one lives through them (Kerby, 1991). Identity is something actively constructed in an on-going basis, it is not merely conditioned by cultural, national, or external exigencies but more on the individual's ability and willingness to exercise agency (Kumaramadivelu, 2012). Agency conceived (in general terms) as 'the socioculturally mediated capacity to act' (Ahearn, 2001, 112) foregrounds identity as constructed in relationship with others and as a result it is undoubtedly extended from the past and stretching into the future (Wenger, 1998).

Thus, the notion of identity may come into play as a two-way process: the way we speak about us and others (affiliation) and the way we are spoken about (attributions) (Fairclough, 1992). In this regard, the concept of identity, I will uphold in this study, is understood depending on its connection to the language learning experiences learners' possess and mostly understood as situated by traces of acting (Agency) and its relation to the world (Subjectivity). To this respect, identity is how we construct ourselves through the narratives that we share with each other (Bruner 1986). Arguably, identity can be framed by narrative as experience and a meaningmaking phenomenon (Clandinin \& Connelly, 2000).
To this respect, identity may be indeed a matter of positioning (Davies \& Harré, 1999). In applied linguistics or, more specially, in language learning and teaching, it is now acknowledged that both learners and teachers make sense of their experiences by telling stories, and while doing so their identities get constructed or they get to construct their identities (Barkhuizen, 2008). It has been argued by Johnson and Golombek (2011: 486) that narratives play an important role as mediational means in teacher education, or in their professional development of teachers and their language practices, an argument that could be extended to language education, or to learners and their efforts to master languages.

Positioning is defined as "the discursive process whereby people are located in conversations as observably and subjectively coherent participants in jointly produced storylines" (Davies \& Harré, 1999: 37). This implies that one can be positioned by another or by oneself. Thus, the term positioning is essential to understand identity, as narrative is a means by which individuals define and recreate themselves through the discursive construction of identity (Martinez \& Roldan, 2003). Positioning embodies the idea of self, a self that is discursively constructed. According to Davies \& Harré (1999), accepting or refusing subject positions are only available through their own or through others' discursive practices. Therefore positioning presents the notion of identity as socially produced within relations of power (Foucault, 1970; Bakhtin, 1981; Wenger, 1998).

Van Langenhove and Harré (1999) echo this by arguing that positioning could also be strategic, meaning that people will tell different stories about themselves depending on how they want to be presented. Consequently, identity and life story must be herein understood fundamentally from their interwoven relationship whereby the learner as an individual can construct her/his own language learning identity, as something dynamic, negotiated, transformed and achieved (Bernstein, 2000). 
Bearing this in mind, positioning as theory contributes to my understanding of identity, which is essential to comprehend learners' language-learning experiences since identity formation takes place over significant periods of time (Wenger, 1998) and it is permeated by positioning and the contexts and experiences where it develops.

\section{Learner and Language learning}

Language learning undoubtedly can be seen from different perspectives. Nonetheless, as the intention here is not to account for historical foundations but rather more epistemological ones, I will discuss key aspects of sociocultural theories drawn on L. S. Vygotsky $(1978,1987)$ that may be informative for the reader to come to understand learning within/for a narrative study. From this perspective, learning is conceived as a social process. As such, it is culturally and historically situated (Norton \& Toohey, 2001). This notion directs special attention to the activities provided for learners in their diverse environments. Nonetheless, many researchers have not typically treated social context as a variable that influences individual functioning (Juffs, 1996; Corder,1967; Ellis, 1997).

I will then take up the aforementioned to make clear that this study, as a whole, mainly looked into learners' language learning experiences narrated and embedded in an EFL context, to trace how students' life stories were either shaping or constructing the learners' own experiences and identities as language learners.

\section{Context and contextualization}

The manuscript presents the results of a qualitative research study that looked into EFL learners' language learning experiences through the collection of their life stories as language learners. In this regard, 10 young-adult learners, members of a private but non-profit English institution in Bogota, Colombia and whose ages ranged from 20 to 36 six years old, participated for a period of more than six months in a number of two life story interviews that aimed at providing an account for their language learning experiences regarding English as a foreign Language.

This study was carried out in an adult English program in which oral and written communication skills were key components. Nonetheless, the study did not make use of such skills to develop, instead, it was embedded in a tutoring system that was a space offered by the institution to those learners, who in spite of being taking regular classes seemed to have different learning difficulties when being exposed to the institute's methodology and class routine.

The tutoring system capitalizes on the fact that learners' experiences are to be used to boost the new learning experience so that they can relate the new learning activity. To this respect, and of particular note is the fact that it is conceived not as a contentbased session intended to solve neither tutee's difficulties with respect to book items or units seen in class, nor their questions for exams (e.g. assessment activities or projects) but to explore the tutee's special learning situation and suggest actions to overcome certain difficulties in this field. This implied a different approach to language learning in which the focus was on how learners learn the language and use it to express their own information.

Therefore, as by being a teacher/tutor/researcher, I started wondering about the learners current results learning the language and their previous experiences with it. All this as a result of informal interviews were learners with difficulties claimed to be voiceless in relation to all the dynamics and social interactions in which they were immersed and that were affecting their language learning processes. In such interviews, it was made evident that class activities and processes regarding language learning were having either little or no connection to learners' everyday realities as language learners and subjects, and that their voices as learners were not being taken into account to overcome learning difficulties.

I started doing some preliminary research about the importance of sharing experiences in the classroom and I found different qualitative inquiry approaches to do so; approaches that could help me 
understand language teaching and learning from the learners' perspective. In this sense, I considered that a focus on narrative content could contribute to a richer and more rounded understanding of learning as lived experiences. Therefore, I started collecting some learners' reflections since June 2012. In those written texts collected, it was interesting and intriguing to see that learners came to the classroom having individual and singular stories about themselves as learners, professionals and members of different groups; stories and experiences that frequently were not taken into considerations as background information to help myself in the teaching activity.

Concerning this, many of the learners expressed bringing a background that related language learning to past experiences. Memories about relationship with teachers, classmates and the language itself were portrayed in those texts.

However, I have had a difficult situation learning the language, with the previous teacher I felt intimidated, It seems to me that she was predisposed against me and I didn't get on well with her. If I didn't prepare class I believed that she judged me and I couldn't enjoy the class. But, I didn't spoke with her so I am not certain about her opinion. Concerning classmates, I've never had a problem with them. In fact, I value other people's participation and point of view. Regarding information l've never had a problem neither. In conclusion, in my experience as a student l've been given friendly treatment and I've been so active in class that l've never been left behind.

Student 1. Reflection Task, September 2013.

Being one among many, the reflection unveils a feeling of intimidation produced in the learner as result of behaviors, actions or comments made by a teacher and action taken towards learning. This feeling of intimidation was for the learner the result of judgments that to some extent were hindering the learning process.
In a different reflection, another learner acknowledged, insecurity and anxiety as some of the causes that were having an impact on the understanding of the learned language. Arguably, in both reflections, learners made explicit that language-learning difficulties were the result of classroom realities that form their own perspectives, and they seemed to be decontextualized from their own needs.

Throughout my live, to master the American language really has been more than a wish, a need which at the beginning, it never was easy to do it due to the fact in my last schools there was not a very detailed or thorough preparation about this subject, therefore it has been necessary to take courses, training by myself and this and has led to have stumbles in the sense that there are some factors that affect me in the learning such as the anxiety, insecurity, nerves, pressure that causes us mental blocks which makes our learning is affected as this makes us live experiences in which I have been through sorrows not being able to understand and keep the conversation with the teachers about the subject and classmates. It archive to create fears oneself, fears to express in a language other than native language.

Student 3. Reflection Task, September 2013. 
Thanks to these and other interviews and reflections collected, I decided to build this study on the idea that each learner possesses a language learning identity that is not only dynamic and fragmented but also negotiated, transformed and achieved (Bernstein, 2000) through discourse (Le Page, 1986) and experience.

\section{Data and findings}

This study took on a Narrative Inquiry approach, understood both as a research methodology and as a "mode of thought, communication and apprehension of reality" (De Fina \& Georgakopoulou, 2012, 15) to dig into participants' contexts through examining holistically the complexity of their language learning in the setting where experiences emerged. Narrative inquiry allowed me as a researcher to understand how language learners organize their experiences and identities and represent them to themselves and to others, in a field that very often favors abstract, theoretical understanding of processes over the particular, contextualized knowledge of participants (Firth and Wagner, 1997).

The study revealed that firstly, learners' language learning experiences are an assembly of generative decisions, which are governed by their desires, affinities and fears. Data indicated that the learners' language learning experiences have important implications for understanding how the learner's identities are shaped by the relationship with other. The aforementioned was unveiled when in life stories interviews, life stories accounted for learners' own perceptions of the environment.

P 4: Informant-006-09-07-2013.rtf - 4:22 Co-

des: [How others see me as a learner]

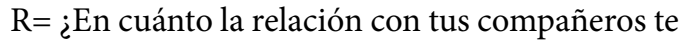
sentiste alejada de ellos?

$\mathrm{I}=$ si al principio eso sí pero ahorita ya es porque no los conocía bien. Como en el colegio yo tuve problemas de timidez de con lo que te digo, que la gente me discriminada que me decían mongólica y eso, que eso me molestaba. En cambio acá en ningún momento siento que los muchachos me discriminan ni nada de eso.

P4: Informant-006-o9-07-2013.rtf - 4:22 Codes:

[How others see me as a learner]

$\mathrm{R}=$ Regarding the relationship with your classmates, did you ever feel away from them?

I = yeah, at first I did, but right now it is because I did not know them well. Just like in school I had problems with my shyness, people used to discriminate me, they named me "Mongolica" and they told me that! It bothered me. But, in here it has not happened like before. I feel that the boys do not discriminate me or anything.

The individual accounting for this life story constructed an image of the learning environment from the eyes of the other. To this respect, data also indicated that when others position learners, they display a non-unitary identity (Weedon, 1987) that recognizes and resists the discourse of the "other". According to Davies and Harré (1990) in taking a position a person also takes on a way of understanding; therefore, learners take the understanding assigned by the discourse used by others, for the case, this learner appears to be fully aware of the derogatory name-calling practice where she was positioned as a "mongólica". When the learner struggles to find a personal way to identify himself/herself with the learning community, the language learning experience becomes the intersection between discourses and personal representations of struggle.

As argued by Willet (1995) people act and react to one another, they also construct social relations (e.g., hierarchical relations), ideologies (e.g., inalienable rights of the individual), and identities (e.g., good student) and this is how learning occurs. Thus, the previous life story discloses that different constructions that are contingent upon the environment and that modify and determine their language learning identity as a striking feature altered by personal and social views of the learning experience.

Data also indicated that the teacher's role has been experienced and defined by the language 
learner in multiple ways. From being supportive to the one who hinders the learning experience.

P 2: Informant-010-19-09-1013.rtf - 2:91 Code:

[Teacher as a bully]

Pues al comienzo muy bueno para que, con el profesor tu aprendes o aprendes, pero yo digo que el dinamismo que el maneja o la, el método que él tiene no es el adecuado, ¿Por qué? Porque el en vez de explicarte de buena manera, bueno no estamos diciendo que él estaba con bebes, no él estaba con personas grandes, pero no era la forma y él nos trataba como a las patadas, nos decía "losers" , tal vez lo decía como chiste pero no parecía: nos decía "losers" perdedores nos decía que nosotros teníamos los humos muy altos, que él no los iba a bajar, nos decía que, que " como era posible que parte del salón estuviera tan mal.

P 2: Informant-010-19-09-1013.rtf - 2:91 Code:[Teacher as a bully]

Well, at the beginning everything was okay, with this teacher either you learn or learn, but I argue that dynamism that he uses or the method he follows is not right, why? Because instead of explaining in a good way, well we're not saying he was with babies, no it was with grown-ups, but it was not the way and he treated us like rude, he told us "losers", perhaps he said this as a joke but it did not seem like that: he told us "losers", he told us that we had very high ego and that he was not going to take it down, we used to say as well, "how is possible that part of the class can be this bad"

Although learners can accept or refuse subject positions that are made available through their own or through others' discursive practices (Davies \& Harré, 1999) learners' identities are undoubtedly here the result of a situated learning tension. Learner's identity is socially produced within relations of power (Foucault, 1970; Bakhtin, 1981; Wenger, 1998). Indeed, this notion of the superior teacher resonates with teacher's approval discourses stated by Baxter (2002). Interestingly, it is the teacher who discursively positions and configures the learner as a result of situated struggle within the EFL environment; the learner is a "loser" unable to learn the target language; a struggle that as stated by the own learner shows the teacher as a figure of privileges, someone who favors learners over others.

Davies and Harré (1999) connect this phenomenon to participation in discursive practices. Thus, even while positioning and being positioned, learners may remain committed to a pre-existing idea of themselves that is made explicit by the teacher; this indeed portrays that learners' identity here may not be negotiable because they may be positioned in powerful ways which they are unable to resist (Blackledge and Pavlenko 2001). To this respect and according to Weber's theory of social action (1991), individuals do exert control over their own actions rather than being passive recipients of society's directives. They have the ability as agents to act differently according to social contexts and to respond reflexively in the face of the behavior of others. In his regard, language learning from the previous narrated account cannot be understood just as an abstract structure isolated from the environment of learning or personal context. It must be seen up to the experience itself. What is meant here is that learners, when positioned as "losers", resist and act upon in order to transform such positioning. This can be exemplified by making use of verbatim words from the same transcription of the life story previously used:

P 2: Informant-010-19-09-1013.rtf - 2:72 Codes:

[The confrontation]

Hablamos con él, yo me acuerdo que hablamos tres personas con él le dijimos "no nos gusta su actitud, no nos gusta su forma de aprendizaje, no nos gusta su método por favor cámbielo porque nosotros estamos pagando acá.

P 2: Informant-010-19-09-1013.rtf - 2:72 Codes: [The confrontation]

We talked to him, I remember that three more people and I did so and we told him: "we do not like your attitude, we do not like the way you 
teach nor the method you follow, please change it, because we are paying here!

The excerpt above serves to show how learners resist and act upon teacher's positioning. For Foucault (1974) the power of discourses lies in their operation as tacit givens that conceal the mechanisms by which they discipline subjects, construct social relationships and the possibilities for particular thought and actions. Learning as the site of struggle between the teacher and learners, discloses how learners confront and face the authority of the teacher by pointing out weaknesses in his/her teaching methodology and his/her attitude towards them. Nonetheless, this emerges as the result of the "loser" label. Surprisingly, learners exert a role that goes beyond accepting what is imposed or given; they move from resisting to exerting agency.

To this respect, Weedon argues, "to speak is to assume a subject position within discourse and to become subjected to the power and regulation of the discourse" (1987). This position, seen from the data examined, argues that discourses are not only of power but also from knowledge. Arguably, knowledge is also perceived as a decisive factor within the learner's language learning experience. Thus, learners conceived as confirming and transforming accounted for different ways of dealing with different obstacles within the EFL classroom.

Remarkably, learners claimed that they have been labeled based on their own abilities to command and use the language; learners' own identities are impacted upon their acceptance or rejection of the label. Hence, being categorized in terms of having language problems or different conditions to master the language may come to shape learners' experiences of self-identity across a range of social relationships either negatively or positively.

Some of them, positioned as good language users, were able to make deliberate choices with respect to language learning, including the choice to resist learning or perform in the target language in expected ways (Pavlenko, 2007). The excerpt below presents how by resisting to others' positioning and constructions learners engage in forced negotiations of their identities:

P 3: Informant-010-19-09-1013.rtf - 3:19 Code: [The go getter learner] [The teacher-dependent learner] [The teacher's attitude-dependent learner]

Entonces yo me acuerdo tanto que él me dijo "Wendy usted está mal, yo no sé usted que hace acá" cuando una persona te dice eso, me bajo totalmente la moral, dije "Dios mío ¿Qué estoy haciendo acá? ¿Qué pasó?” porque iba tan bien de un proceso, con este otro profesor que la verdad dije "pues ya estoy mejor" pero después veo con este tipo y me dice “¿usted qué hace acá?” imagínate, entonces me sentí muy mal, entonces yo dije "No, voy a demostrarle que yo sí puedo".

P 3: Informant-010-19-09-1013.rtf - 3:19 Code: [The go getter learner] [The teacher-dependent learner] [The teacher's attitude-dependent learner]

So, I remember that once he told me "Wendy, you are wrong, I do not know what you are doing here" when someone tells you that, it totally let me down; then I said " My gosh, what am I doing here? What happened? Because I was doing really well with the other teacher that I said "I am way better" but then I have classes with this guy and tells me "what do you do here?" so, I did not feel okay, so I said "No, I am going to prove him that I can make it".

In this excerpt of a life story, the learner's accounts for one's capacity to make decisions to look for or strategies to cope with obstacles in the learning experience. Gao (2010) believes that learners' strategy use is evidence of their agency in the learning process because strategy use involves making choices and is the result of learners' exercise of agency. Although it does more with strategic learning efforts, it puts agency as relevant for learners to find ways to improve their opportunities to learn and enhance the conditions under which they learn (Reeve \& Tseng's, 2011). 
With respect to agency, this notion situated within the learners' language learning experience embodies learners' participation and knowledge of the language as constructed through a process of taking actions in one's learning environment. Moreover, the implication is that it seems that the most transformative learning experiences will be those that are directed by the learner's own endeavors and curiosities. Bandura (2001, 2) highlights the role of agency in the self-regulation of learning by stating that "the core features of agency enable people to play a part in their self-development, adaptation, and self-renewal with changing times".

When learners tell and reflect upon their own perceptions towards teachers, they position their own identities by acknowledging the need of being seen by the teacher. This acknowledgment both triggers and limits language learners' own interest in acting in a way where their participation and involvement in their learning processes is adjusted to the situation lived. Arguably, agency seems to be contingent upon the belief that one can achieve a different personal involvement embedded within existing structures afforded by the context in which the learning experience is situated.

Data also indicated that learners' beliefs influence how they learn and how they can learn (Bandura, 1986). Particularly, beliefs in the life stories collected indicate that learners' perceptions regarding their language learning experience and learning environment change over time. This argument is exemplified in the following excerpt:

P 2: Informant-010-19-09-1013.rtf - 2:33 Codes:

[Learners' assumptions about teachers]

"El profesor tenía también como sus preferidos, entonces uno decía como que: "yo quiero también participar, quiero también hablar” y él “ino!” siempre sus preferidos eso también es un punto que hay que aclarar, porque los profesores acá tienen sus preferidos, miran más a los que son buenos, entonces como tienen sus preferidos, él siempre pasa, él siempre todo, él siempre todo y ¡no!, eso no debería ser así porque con el otro profe yo era buena y hablaba ahora solo porque él no me deja no puedo ni hablar."

P 2: Informant-010-19-09-1013.rtf - 2:33 Codes: [Learners' assumptions about teachers]

"The teacher had a preference for some people, So, I used to say like: "I want to participate too, I want to speak" and "No!" He had always his preferences; this is something that I have to state here, because teachers here have his preferences, They pay more attention to those who are good. So, as they prefer some students, he is always up front, he is all everything and no!; this should not be the way since with the other teacher I was good and I used to speak, now just because this one does not allow me, I can barely do so.

In here, the learner conceives the teacher as someone who prioritizes and values language command and performance over the willingness to participate and improve. From the learner's eyes, it is the teacher who disregards learner's self-encouragement and desire of motivation. Nonetheless, this finding also indicates that those successful learners favored by the teacher were more proficient and confident, hence more motivated. It could be stated as a result of this analysis that a teacher-led classroom alters learners' acting within the language learning experience. Learners' actions cannot produce the outcomes they desire after being conditioned by the teacher. Learners may display little incentive to act or to persevere in the face of difficulties encountered within the EFL classroom.

Although the foregoing connects to the desire of performing better, implications go beyond the linguistics applications of the learning experience. As reported by McAdams (1993) stories can be a factor in healing and personal growth, in enhancing individuals' self-esteem and lead insights into future possibilities (Atkinson, 1998). Thus, when learners tell and reflect upon their own perceptions towards teachers, they position their own identities by acknowledging the need of being seen by the teacher. This acknowledgment both triggers and limits their own interest in acting in a way where 
their participation and involvement in their learning processes is adjusted to the situation lived.

\section{Conclusions}

Learners' accounts of the language learning experience are especially important to understand how learners' identity is shaped or constructed. Learners' capacity to act within the possibilities afforded by the social structures in which they are situated (Miller, 2003) unveils that learners are able to act upon the imposition and discourses of others. Surprisingly, learners' life stories shed light into discourses of positioning in which others positioned them. From this perspective, learners displayed some sort of engagement and acting with a powerful discourse, they participated by limiting and enabling their own agentic selves. Then, the learners' language learning experiences unveiled how different positions, towards learners, depicted ways of understanding (Davies \& Harré, 1999, 46). In particular, "both learners and teachers have a degree of agency in how they position themselves in interactions but this agency is interlaced with the expectations and history of the community" (Linehan \& McCarthy, 2000, 442).

As a concluding element in this study, language learning seemed to be governed by learners' frustrations, fears and obstacles; learners' identity is also forged through the acceptance and struggling with others; experiences in learning are seen up to the environment and the subjects who interfere or take part in it and expressions of agency through the construction of identities draw on a range of normative but also individualized experiences that are the result of learners' own decision making process to resist others' positioning. Nonetheless, if it is acknowledged that both learners and teachers make sense of their experiences by telling stories, and while doing so their identities get constructed or they get to construct their identities (Barkhuizen, 2008) this study puts forward, grounded on the data collected, that the language learner must be considered not only as a possessor of linguistic knowledge (Ausubel \& Fitzgerald, 1962) but also as someone who needs to be defined as well by the experience it brings into the learning process.

To this respect, this would result in analyzing learner's individual reality in order to situate learning within the perspective of the individual avoiding institutionalizing or standardizing learning processes. It would also imply that the language learner is more than an abstract and instrumentalized notion and emerges more as a creation of mixed experiences situated in the learners' realities. Nevertheless, in order to truly understand learner's learning experiences and their identities as language learners it is required that we listen to their voices and the stories they tell about their learning and lives; learning how EFL language learners experience the learning act, is undoubtedly informative for teachers and educational contexts.

After having dug into learners' life stories it is also necessary to pin point that learning can be situated now as a process of participation in which the community of practice entails the negotiation of ways of being a person in that context (Wenger, 1998). Thus, learning becomes a fragmentation of experiences that locate identity as a notion of imagination. Arguably, the notion of imagination as a way to appropriate meaning and create new identities (Anderson, 1991; Wenger, 1998) may be reflected in the learners' desire to be part of the community and accepted by those who are in it.

\section{References}

Ahearn, L. M. (2001). Language and agency. Annual Review of Anthropology, 30, 109-137.

Anderson, B. (1991). Imagined communities: reflection on the origins and spread of nationalism. London: Verso.

Atkinson, R. (1998). The life story interview. Thousand Oaks, CA: Sage Publications.

Ausubel, D. P. \& Fitzgerald, D. (1962). Organizer, general background, and antecedent learning variables in sequential verbal learning. Journal of Educational Psychology, 53 (6), 243-249.

Bandura, A. (1986). Social foundations of thought and action: a social cognitive theory. Englewood Cliffs, NJ: Prentice Hall. 
Bakhtin, M. (1981). The dialogic imagination. Austin: University of Texas Press.

Bandura, A. (2001). Social cognitive theory: An agentic perspective. Annual Review of Psychology, 52, 1-26.

Barkhuizen, G., Benson, P., Chik, A. (2014). Narrative inquiry in language teaching and learning research. New York, NY: Routledge

Baxter, J. (2002). Competing discourses in the classroom: a post-structuralist discourse analysis of girls' and boys' speech in public contexts. Discourse and society, 13 (6), 827-842.

Bell, J. C. (2002). Narrative inquiry: More than just telling stories. TESOL Quarterly: 36 (2), 207-213.

Blackledge, A. and A. Pavlenko. (2001). Negotiation of identities in multilingual contexts. The International Journal of Bilingualism, 5(3): 243-57.

Benson, P., \& Nunan, D. (2014). Learners' stories: Difference and diversity in language learning. Cambridge: Cambridge University Press.

Berger, P. L. \& Luckmann, T. (1966). The Social Construction of Reality: A Treatise in the Sociology of Knowledge. New York: Anchor.

Bernstein, B. (2000). Pedagogy, symbolic control and identity: Theory, Research Critique. Lanham: Rowman \& Littlefield publishers.

Bruner, J. (1990). Acts of meaning. Cambridge MA: Harvard University Press

Bruner, J. (1986). Actual minds, possible worlds. Cambridge MA: Harvard University Press.

Charmaz, K. (2006). Constructing grounded theory. A practical guide through qualitative analysis. London: Sage.

Clandinin, D. J. and Connelly, F. M. (2000). Narrative inquiry experience and story in qualitative research. San Francisco: Jossey-Bass Publishers.

Clandinin, D. J. and Connelly, F.M. (2000) Narrative Inquiry. In J. Green, G. Camilli, \& P. Elmore, Handbook of complementary methods in education research.

Corder, S. P. (1967). The significance of learner's errors. IRAL: International Review of Applied Linguistics in Language Teaching. 5(4): 161-170.

Davies, B. \& Harré, R. (1999). Positioning and personhood. In: R. Harré \& L. van Langenhove. Positioning theory: moral contexts of inventional action. Oxford: Blackwell.
Davies, B., and R. Harré. (1990). Positioning: the discursive production of selves. Journal forthe Theory of Social Behavior. 20 (1), 43-63.

De Fina, A. \& Georgakopoulou, A. (2012). Analyzing Narrative: Discourse and sociolinguistic perspectives. Cambridge: Cambridge University Press.

Ellis R. (1997). Second Language Acquisition. Oxford: Oxford University Press.

Fairclough, N. (1992). Discourse and social change. Cambridge, England: Polity Press.

Firth, A. \& Wagner, J. (1997) On discourse, communication, and some fundamental concepts in SLA research. Modern Language Journal, 81(3), 235-300.

Foucault, M. (1970). The order of things: An archeology of the human sciences. New York, NY: Pantheon.

Foucault, M. (1974). The archeology of knowledge. London: Tavistock.

Gao, X. (2010). Autonomous language learning against all odds. System, 38 (4), 580-90.

Johnson, K. E. \& Golombek, P. R. (2011). The transformative power of narrative in second language teacher education. TESOL Quarterly, 45 (3), 486-508.

Juffs, A. (1996). Learnability and lexicon. Theories and second language acquisition research. Amsterdam: John Benjamins.

Kerby, A. P. (1991). Narrative and the self. Bloomington, IN: Indiana University Press.

Kumaravadivelu, B. (2012). Individual identity, cultural globalization and teaching English as an international language: The case for an epistemic break. Teaching English as an International Language: Principles and Practices. Alsagoff, L., Renandya, W., Hu, Guangwei \& McKay, S. (Eds.). New York: Routledge.

Lantolf, J. (2000). Sociocultural theory and second language learning. Oxford: Oxford University Press.

Le Page, R. (1986). Acts of identity. English today, 8, 21-24.

Linehan, C., \& McCarthy, J. (2000). Positioning in practice: Understanding participation in the social world. Journal for the Theory of Social Behaviour, 30, 435-453.

McAdams, D. P. (1993). Personal myths and the making of the self. New York: Guildford Press.

Martinez and Roldan, C. (2003). Building worlds and identities: A case study of the role of narratives in bilingual literature discussions. Research in the Teaching of English, 37, 491-52. 
Miller, J. (2003). Audible difference: ESL and social identity in schools. Clevedon: Multilingual Matters.

Norton, B. (2000). Identity and language learning: Gender, ethnicity and educational change. London: Longman/ Pearson Education.

Norton, B., \& Toohey, K. (2001). Changing perspectives on good language learners. TESOL Quarterly, 35 (2), 307-322.

Pavlenko, A. (2007). Autobiographic narratives as data in applied linguistics. Applied Linguistics, 28 (2), 163-188.

Reeve, J. \& Tseng, C. M. (2011). Agency as a fourth aspect of students' engagement during learning activities. Contemporary Educational Psychology, 36, 257-267. doi:10.1016/j.cedpsych.2011.05.002.

Roberts, B. (2002). Biographical research. Buckingham, UK: Open University Press.

Rubdy, R. (2009). Reclaiming the local in teaching EIL. Language and intercultural communication, 9, 156-74.

Sikes, P., \& Gale, K. (2006). Narrative approaches to educational research: research in education. Retrieved from: http://www.edu.plymouth.ac.uk/resined/narrative/ narrativehome.htm.

Stanley, L. and Temple, B. (2008). Narrative methodologies: subjects, silences, reading and analyses'. Qualitative Research, 8, 275-81.
Taylor, S. (2003). A place for the Future? Residence and continuity in women's narratives of their lives, Narrative Inquiry, 13, 193-215.

Van Langenhove, L., \& Harré, R. (1999). Introducing positioning theory. In R. Harré, \& L. van Langenhove (Eds.). Positioning theory. Oxford: Blackwell Publishers Ltd.

Weedon, C. (1987). Feminist practice and poststructuralist theory. London: Blackwell.

Weber, M. (1991). The nature of social action. In Runciman WG (ed.). Weber: Selections in Translation. Cambridge: Cambridge University Press.

Wenger, E. (1998). Communities of practice: Learning, meaning, and identity. Cambridge: Cambridge University Press.

Vygotsky, L. S. (1978). Mind in society: The development of higher psychological processes. Cambridge, MA: Harvard University Press.

Vygotsky, L. S. (1987). Thinking and speech. In R. W. Rieber \& A. S. Carton (Eds.). The collected works of L. S. Vygotsky. Vol. 1. Norris Minick (Trans.). New York and London: Plenum, 243-286. 